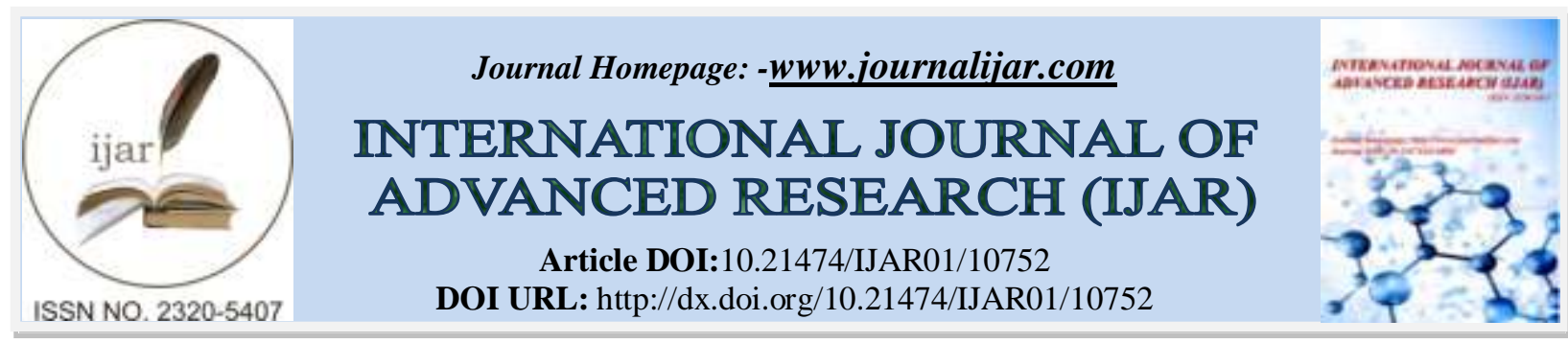

RESEARCH ARTICLE

\title{
AMELIORATIVE ACTIVITY OF ASCORBIC ACID (AA) ON PARAQUAT (PQ) INDUCED SERUM BIOCHEMICAL ALTERATIONS IN EXPERIMENTAL RATS
}

\section{Kothinti Busa Ashok Kumar Reddy ${ }^{1}$, Mylaram Jeevanalatha ${ }^{2}$, Mekala Lakshman ${ }^{3}$ and Matukumalli Usha Rani $^{4}$}

1. Post-graduate, Department of Veterinary Pathology, College of Veterinary Science, PVNRTVU, Rajendranagar, Hyderabad-500030, India.

2. Assistant Professor and Head, Department of Veterinary Pathology, College of Veterinary Science, PVNRTVU, Mamnoor, Warangal-506166, India.

3. Professor and Head, Department of Veterinary Pathology, College of Veterinary Science, PVNRTVU, Rajendranagar, Hyderabad-500030, India.

4. Professor, Department of Veterinary Pharmacology and Toxicology, College of Veterinary Science, PVNRTVU, Rajendranagar, Hyderabad-500030, India.

\section{Manuscript Info}

Manuscript History

Received: 05 February 2020

Final Accepted: 07 March 2020

Published: April 2020

Keywords -

Paraquat, Ascorbic Acid, Serum Biochemistry

\section{Abstract}

The present study aimed to investigate the protective effect of ascorbic acid on paraquat induced serum biochemical alterations in experimental rats. Forty-eight (48) male albino Wistarrats were randomized into four (4) groups consisting of twelve (12) in each. Group 1- Control. Group 2 - Paraquat at the rate of $40 \mathrm{mg} / \mathrm{kg}$ b.wt. Group 3 - Ascorbic acid at the rate of $250 \mathrm{mg} / \mathrm{kg}$ b.wt. Group 4 - Paraquat at the rate of $40 \mathrm{mg} / \mathrm{kg}$ b.wt + Ascorbic acid at the rate of $250 \mathrm{mg} / \mathrm{kg}$ b.wt. The treatment regimens were administered by oral gavage once daily for twenty-one (21) days. Significantly $(\mathrm{P}<0.05)$ increased activity of aspartate transaminase, alanine transaminase, alkaline phosphatase, blood urea nitrogen and serum creatinine and significantly $(\mathrm{P}<0.05)$ decreased activity of total protein was observed in group 2 on $7^{\text {th }}$ and $21^{\text {st }}$ day of experiment. Cotreatment with ascorbic acid showed a remarkable protection against the parameters investigated possibly via antioxidant defence mechanism.

\section{Introduction:-}

Paraquat (N, N' - dimethyl-4, 4'-bipyridinium dichloride - PQ) is a quick-acting and non-selective contact herbicide with an excellent weeding effect (Suntres, 2002). It is highly toxic to both humans and animals when absorbed via ingestion, skin contact, or inhalation (Parvez and Raisuddin, 2006 and Neves et al., 2010). The PQ exerts its toxicity through generation of reactive oxygen species (ROS) leading to cell damage or apoptosis (Hu et al., 2017). Lung is the primary target organ of PQ poisoning due to its accumulation through highly developed polyamine uptake system, resulting in acute respiratory distress syndrome (ARDS), acute, subacute lung injury and pulmonary fibrosis (Papiris et al., 1995; Hemmati et al., 2002; Huang et al., 2005, Mainwaring et al., 2006 and Lakshman et al., 2015). The PQ also damage the liver, kidneys, heart and central nervous system (Khodayar et al., 2014). The cause of death in PQ toxicity is mainly due to respiratory failure due to an oxidative insult to the alveolar epithelium with subsequent obliterating fibrosis (Suntres, 2002). However, clinical intervention of PQ poisoning is often 
unsuccessful due to a lack of effective treatments (Baltazar et al., 2013) and hence, there is a need to study the effective antidotes against PQ induced toxicity. An emphasis has been placed on the use antioxidants as a treatment modality for PQ poisoning to combat oxidant induced cellular damage (Suntres, 2002).

Ascorbic acid (AA) being an antioxidant, is effective in scavenging oxygen free radicals (Okolonkwo et al., 2014). In the present study, protective effect of AA was evaluated against PQ induced serum biochemical alterations.

\section{Materials and Methods:- \\ Experimental animals:}

Forty-eight (48) male albino Wistar rats weighing 200-250 grams were procured from Sanzyme Laboratories Ltd., Hyderabad. The rats were housed in solid bottom polypropylene cages at Ruska Labs, Hyderabad and were maintained in controlled environment $\left(20-22^{\circ} \mathrm{C}\right)$ throughout the course of experiment. Sterile husk was used as standard bedding material. All the rats were provided with standard pellet diet procured from Vyas Labs, Uppal, Hyderabad and deionized water at ad libitum throughout the experimental period. The experiment was carried out according to the guidelines and prior approval of Institutional Animals Ethics Committee (IAEC-No.02-2019).

\section{Drugs and chemicals:}

Paraquat $\left(\right.$ GRAMOXONE $^{\circledR}$ - 24\% w/v solution) was procured from Seed Research and Technology Center, Professor Jayashankar Telangana State Agriculture University, Rajendranagar, Hyderabad which was manufactured by Syngenta India Ltd., Delhi. Ascorbic acid (Vitamin C) as L-ASCORBIC ACID was obtained from S.D. FineChem Ltd., Mumbai, India. Aspen biochemical kits were purchased from Rapid Diagnostics Pvt. Ltd., Delhi to evaluate serum biochemical parameters.

\section{Experimental design:}

A total of 48 male albino Wistar rats were randomly divided into four (4) groups consisting of twelve (12) animals in each.

Group 1 - Control

Group 2 - PQ (@ $40 \mathrm{mg} / \mathrm{kg}$ b.wt)

Group 3 - AA (@250 mg/kg b.wt)

Group 4 - PQ (@40mg/kg b.wt) + AA (@250mg/kg b.wt)

The dose regimens were administered per os (p.o.) once daily for a period of three (3) weeks. The rats were monitored for clinical signs and death.

\section{Serum biochemistry:}

Approximately, $2 \mathrm{~mL}$ of blood was collected from each rat (retro-orbital plexus) through capillary tube into clot promoting vacutainers and allowed to clot for 3-4 hours, later centrifuged at 20,000 rpm for 10 minutes; serum was separated into Eppendorf tubes and stored at $20^{\circ} \mathrm{C}$. The stored serum samples were used to estimate serum biochemical parameters by using semi-automatic biochemical analyser (star 21plus-Aspen Diagnostics Pvt. Ltd., Delhi). Serum activities of aspartate aminotransferase (AST), alanine aminotransferase (ALT), alkaline phosphatase (ALP), total protein (TP), blood urea nitrogen (BUN) and creatinine were measured spectrophotometrically according to the protocol given by the commercial kits.

\section{Statistical analysis:}

Data obtained (serum biochemistry) was subjected to statistical analysis by applying one-way ANOVA and using statistical package for social sciences (SPSS) version 25.0. Differences between the means were tested by using Duncan's multiple comparison tests and significance level was set at $\mathrm{P}<0.05$ (Snedecor and Cochran, 1994).

\section{Results and Discussion:-}

\section{Liver function assays:}

Significantly $(\mathrm{P}<0.05)$ higher mean values of AST were observed in group $2(124.59 \pm 2.78$ and $138.69 \pm 4.24)$ when compared to group $1(77.70 \pm 0.31$ and $78.22 \pm 0.26)$, group $3(76.86 \pm 0.68$ and $77.87 \pm 0.94)$ and group $4(94.80 \pm 1.62$ and $102.54 \pm 2.40$ ) rat serum samples on $7^{\text {th }}$ and $21^{\text {st }}$ day of experiment. The results were depicted in Table 1. 
The mean values of ALT in different groups $\left(1,2,3\right.$ and 4) were ranged from $35.84 \pm 0.68$ to $51.37 \pm 4.14$ on day $7^{\text {th }}$ and $37.43 \pm 0.52$ to $62.46 \pm 4.81$ on day $21^{\text {st }}$ of experiment. A significant $(\mathrm{P}<0.05)$ elevation in the mean values of ALT were recorded in group 2 when compared with group 1, group 3 and group 4 rat serum samples on $7^{\text {th }}$ and $21^{\text {st }}$ day of experiment. The results were presented in Table 2.

The mean values of ALP were insignificant between group 2 (134.38 \pm 3.51 and 154.81 \pm 6.09 ) and group 4 $(127.12 \pm 3.14$ and $143.08 \pm 4.50)$ but the values were significantly $(\mathrm{P}<0.05)$ higher when compared to group 1 $(116.38 \pm 2.17$ and $117.63 \pm 2.32)$ and group $3(115.86 \pm 1.48$ and $116.45 \pm 1.77)$ rat serum samples on $7^{\text {th }}$ and $21^{\text {st }}$ day of experiment. The results were showed in Table 3.

Significantly $(\mathrm{P}<0.05)$ decreased mean values of TP $(4.48 \pm 0.12$ and $3.34 \pm 0.15)$ were observed in group 2 when compared to group 1 (7.64 \pm 0.18 and 7.32 \pm 0.14$)$, group 3 (7.81 \pm 0.17 and $7.56 \pm 0.18)$ and group $4(6.47 \pm 0.24$ and $5.58 \pm 0.22)$ rat serum samples on $7^{\text {th }}$ and $21^{\text {st }}$ day of experiment. The results were depicted in Table 4.

Kidney function assays:

A significant $(\mathrm{P}<0.05)$ increase in the activity of serum creatinine was recorded in group $2(2.62 \pm 0.07$ and $2.97 \pm 0.26)$ as compared to group $1(1.27 \pm 0.05$ and $1.43 \pm 0.10)$, group $3(1.33 \pm 0.04$ and $1.46 \pm 0.08)$ and group 4 $(2.05 \pm 0.07$ and $1.90 \pm 0.22)$ rat serum samples on $7^{\text {th }}$ and $21^{\text {st }}$ day of experiment. The results were showed in Table 5 .

Significantly $(\mathrm{P}<0.05)$ higher mean values of serum BUN were recorded in group $2(18.65 \pm 1.21$ and $27.59 \pm 1.96)$ and group $4(16.29 \pm 0.82$ and $21.24 \pm 0.71)$ when compared with group $1(9.38 \pm 0.64$ and $9.46 \pm 0.47)$ and group 3 $(9.45 \pm 0.73$ and $9.87 \pm 0.69)$ rat serum samples on $7^{\text {th }}$ and $21^{\text {st }}$ day of experiment. The mean values between group 2 and group 4 rat serum samples were significant $(\mathrm{P}<0.05)$ only on $21^{\text {st }}$ day but not on $7^{\text {th }}$ day of experiment. The results were presented in Table 6.

In the present study, the mean values of different serum biochemical parameters viz., AST, ALT, ALP, BUN and serum creatinine were significantly $(\mathrm{P}<0.05)$ increased whereas $\mathrm{TP}$ was significantly $(\mathrm{P}<0.05)$ decreased among group 2 rats when compared with group 1 rats on $7^{\text {th }}$ and $21^{\text {st }}$ day of experiment which is an indicative of hepatic and renal damage.

An elevated values of AST, ALT and ALP in group 2 rats might be due to PQ induced lipid peroxidation which damages lipid membrane bilayers of hepatocytes leading to the release of membrane bound enzymes from the damaged cell cytoplasm into circulation. The findings are in agreement with observations of Okolonkwo and Nwachuku (2013); Chen et al. (2015), Shi et al. (2015); Tavakol et al. (2015); Pourahmad et al. (2016) and Ma et al. (2017). Contrary to this, decreased values of ALP were observed in PQ treated group by Costa et al. (2013) which could be due to lipid oxidative damage and this assumption was supported by Vandenberghe (1995) who had explained the ALP inhibition due to oxidative damage to lipid membranes in the canalicular zone which interferes with the bile flow. According to Sastry et al. (1982) and Das and Mukherjee (2000), the depleted TP values could be due to impaired protein synthesis by liver or increased protein loss via kidney excretion.

According to Evers et al. (1983), an increased mean values of BUN and serum creatinine might be due to AKI because the highest concentration of PQ was observed in kidneys after lungs post intoxication. The PQ induced nephrotoxicity associated with direct tubular toxicity, inflammation, oxidative stress and apoptosis might be the cause for elevated BUN and serum creatinine levels (Kimbrough, 1974 and Vale et al., 1987).

Significantly $(\mathrm{P}<0.05)$ reduced mean values of AST, ALT, BUN and serum creatinine, numerically reduced mean values of ALP and significantly $(\mathrm{P}<0.05)$ increased mean values of TP were observed in group 4 when compared to group 2 rats on $7^{\text {th }}$ and $21^{\text {st }}$ day of experiment which could be due to ameliorative effect of AA by protecting critical macromolecules from oxidative damage.

\section{Conclusion:-}

In conclusion, the present study revealed that the AA $(250 \mathrm{mg} / \mathrm{kg})$ supplementation can effectively ameliorate PQ $(40 \mathrm{mg} / \mathrm{kg})$ induced alterations of serum biochemical parameters possibly via antioxidant defence mechanism. 


\section{Acknowledgement:-}

The authors are thankful to P V Narsimha Rao Telangana Veterinary University for providing support and necessary facilities to carry out the research work.

Table 1:- Serum AST activity (IU/L) in different groups.

\begin{tabular}{|l|l|l|}
\hline Group & Day 7 & Day 21 \\
\hline Group 1 & $77.70 \pm 0.31^{\mathrm{c}}$ & $78.22 \pm 0.26^{\mathrm{c}}$ \\
\hline Group 2 & $124.59 \pm 2.78^{\mathrm{a}}$ & $138.69 \pm 4.24^{\mathrm{a}}$ \\
\hline Group 3 & $76.86 \pm 0.68^{\mathrm{c}}$ & $77.87 \pm 0.94^{\mathrm{c}}$ \\
\hline Group 4 & $94.80 \pm 1.62^{\mathrm{b}}$ & $102.54 \pm 2.40^{\mathrm{b}}$ \\
\hline P Value & $*$ & $*$ \\
\hline
\end{tabular}

Values are Mean $\pm \mathrm{SE}(\mathrm{n}=6)$; One-way ANOVA; Means with different superscripts in a column differ significantly at $\mathrm{P}<0.05(*)$.

Table 2:- Serum ALT activity (IU/L) in different groups.

\begin{tabular}{|l|l|l|}
\hline Group & Day 7 & Day 21 \\
\hline Group 1 & $36.60 \pm 0.74^{\mathrm{b}}$ & $38.11 \pm 0.90^{\mathrm{c}}$ \\
\hline Group 2 & $51.37 \pm 4.14^{\mathrm{a}}$ & $62.46 \pm 4.81^{\mathrm{a}}$ \\
\hline Group 3 & $35.84 \pm 0.68^{\mathrm{b}}$ & $37.43 \pm 0.52^{\mathrm{c}}$ \\
\hline Group 4 & $42.72 \pm 3.38^{\mathrm{b}}$ & $52.60 \pm 4.41^{\mathrm{b}}$ \\
\hline P Value & $*$ & $*$ \\
\hline
\end{tabular}

Values are Mean $\pm \mathrm{SE}(\mathrm{n}=6)$; One-way ANOVA; Means with different superscripts in a column differ significantly at $\mathrm{P}<0.05(*)$.

Table 3:- Serum ALP activity (IU/L) in different groups.

\begin{tabular}{|l|l|l|}
\hline Group & Day 7 & Day 21 \\
\hline Group 1 & $116.38 \pm 2.17^{\mathrm{b}}$ & $117.63 \pm 2.32^{\mathrm{b}}$ \\
\hline Group 2 & $134.38 \pm 3.51^{\mathrm{a}}$ & $154.81 \pm 6.09^{\mathrm{a}}$ \\
\hline Group 3 & $115.86 \pm 1.48^{\mathrm{b}}$ & $116.45 \pm 1.77^{\mathrm{b}}$ \\
\hline Group 4 & $127.12 \pm 3.14^{\mathrm{a}}$ & $143.08 \pm 4.50^{\mathrm{a}}$ \\
\hline P Value & $*$ & $*$ \\
\hline
\end{tabular}

Values are Mean $\pm \mathrm{SE}(\mathrm{n}=6)$; One-way ANOVA; Means with different superscripts in a column differ significantly at $\mathrm{P}<0.05(*)$.

Table 4:- Total protein concentration $(\mathrm{g} / \mathrm{dL})$ in different groups.

\begin{tabular}{|l|l|l|}
\hline Group & Day 7 & Day 21 \\
\hline Group 1 & $7.64 \pm 0.18^{\mathrm{a}}$ & $7.32 \pm 0.14^{\mathrm{a}}$ \\
\hline Group 2 & $4.48 \pm 0.12^{\mathrm{c}}$ & $3.34 \pm 0.15^{\mathrm{c}}$ \\
\hline Group 3 & $7.81 \pm 0.17^{\mathrm{a}}$ & $7.56 \pm 0.18^{\mathrm{a}}$ \\
\hline Group 4 & $6.47 \pm 0.24^{\mathrm{b}}$ & $5.58 \pm 0.22^{\mathrm{b}}$ \\
\hline P Value & $*$ & $*$ \\
\hline
\end{tabular}

Values are Mean $\pm \mathrm{SE}(\mathrm{n}=6)$; One-way ANOVA; Means with different superscripts in a column differ significantly at $\mathrm{P}<0.05(*)$.

Table 5:- Serum creatinine $(\mathrm{mg} / \mathrm{dL})$ in different groups.

\begin{tabular}{|l|l|l|}
\hline Group & Day 7 & Day 21 \\
\hline Group 1 & $1.27 \pm 0.05^{\mathrm{c}}$ & $1.43 \pm 0.10^{\mathrm{c}}$ \\
\hline Group 2 & $2.62 \pm 0.07^{\mathrm{a}}$ & $2.97 \pm 0.26^{\mathrm{a}}$ \\
\hline Group 3 & $1.33 \pm 0.04^{\mathrm{c}}$ & $1.46 \pm 0.08^{\mathrm{c}}$ \\
\hline Group 4 & $2.05 \pm 0.07^{\mathrm{b}}$ & $1.90 \pm 0.22^{\mathrm{b}}$ \\
\hline P Value & $*$ & $*$ \\
\hline
\end{tabular}

Values are Mean $\pm \mathrm{SE}(\mathrm{n}=6)$; One-way ANOVA; Means with different superscripts in a column differ significantly at $\mathrm{P}<0.05(*)$. 
Table 6:- Blood urea nitrogen $(\mathrm{mg} / \mathrm{dL})$ in different groups.

\begin{tabular}{|l|l|l|}
\hline Group & Day 7 & Day 21 \\
\hline Group 1 & $9.38 \pm 0.64^{\mathrm{b}}$ & $9.46 \pm 0.47^{\mathrm{c}}$ \\
\hline Group 2 & $18.65 \pm 1.21^{\mathrm{a}}$ & $27.59 \pm 1.96^{\mathrm{a}}$ \\
\hline Group 3 & $9.45 \pm 0.73^{\mathrm{b}}$ & $9.87 \pm 0.69^{\mathrm{c}}$ \\
\hline Group 4 & $16.29 \pm 0.82^{\mathrm{a}}$ & $21.24 \pm 0.71^{\mathrm{b}}$ \\
\hline P Value & $*$ & $*$
\end{tabular}

Values are Mean \pm SE (n=6); One-way ANOVA; Means with different superscripts in a column differ significantly at $\mathrm{P}<0.05$ (*).

\section{References:-}

1. Baltazar, T., Dinis- Oliveira, R. J., Duarte, J. A., de Lourdes Bastos, M. and Carvalho, F. (2013): Paraquat research: do recent advances in limiting its toxicity make its use safer?. Br. J. Pharmacol., 168(1): 44-45.

2. Chen, J. L., Dai, L., Zhang, P., Chen, W., Cai, G. S., Qi, X. W., Hu, M. Z., Du, B. and Pang, Q. F. (2015): Methylene blue attenuates acute liver injury induced by paraquat in rats. Int. Immunopharmacol.,28(1): 808812 .

3. Costa, M. D., de Freitas, M. L., Dalmolin, L., Oliveira, L. P., Fleck, M. A., Pagliarini, P., Acker, C., Roman, S. S. and Brandão, R. (2013): Diphenyl diselenide prevents hepatic alterations induced by paraquat in rats. Environ. Toxicol. Pharmacol., 36(3): 750-758.

4. Das, B. K. and Mukherjee, S. C. (2000): Sublethal effect of quinalphos on selected blood parameters of Labeo rohita(Ham.) fingerlings. Asian Fish. Sci., 13(3): 225-233.

5. Evers, W. D., Hook, J. B. and Bond, J. T. (1983): Paraquat concentration and renal function in mice fed purified and cereal-based diets. Drug-nutrient Interactions., 2(2): 95-104.

6. Hemmati, A. A., Nazari, Z., Motlagh, M. E. and Goldasteh, S. (2002): The role of sodium cromolyn in treatment of paraquat-induced pulmonary fibrosis in rat. Pharmacol. Res., 46(3): 229-234.

7. Hu, X., Shen, H., Wang, Y. and Zhao, M. (2017): Liver X receptor agonist TO901317 attenuates paraquatinduced acute lung injury through inhibition of $\mathrm{NF}-\kappa \mathrm{B}$ and $\mathrm{JNK} / \mathrm{p} 38 \mathrm{MAPK}$ signal pathways. Biomed Res. Int., 2017: 13.

8. Huang, C. J., Yang, M. C. and Ueng, S. H. (2005): Subacute pulmonary manifestation in a survivor of severe paraquat intoxication. Am. J. Med. Sci.., 330(5): 254-256.

9. Khodayar, M. J., Kiani, M., Hemmati, A. A., Rezaie, A., Zerafatfard, M. R., Nooshabadi, M. R. R. and Goudarzi, M. (2014): The preventive effect of atorvastatin on paraquat-induced pulmonary fibrosis in the rats. Adv. Pharm. Bull., 4(4): 345.

10. Kimbrough, R. D. (1974): Toxic effects of the herbicide paraquat. Chest., 65(4): 65-67.

11. Lakshman, M., Sudha, V. and Haripriya, B. (2015): Ultrastructural Pathology of Paraquat (PQ) Induced Acute and Subacute Lung Injury in Experimental Rats. International Journal Science and Research (IJSR)., 6(6):14541458.

12. Ma, J., Sun, F., Chen, B., Tu, X., Peng, X., Wen, C., Hu, L. and Wang, X. (2017): Tissue metabolic changes for effects of pirfenidone in rats of acute paraquat poisoning by GC-MS. Toxicol Ind Health., 33(12): 887-900.

13. Mainwaring, G., Lim, F. L., Antrobus, K., Swain, C., Clapp, M., Kimber, I., Orphanides, G. and Moggs, J. G. (2006): Identification of early molecular pathways affected by paraquat in rat lung. Toxicology., 225(2-3): 15772.

14. Neves, F. F., Sousa, R. B., Pazin-Filho, A., Cupo, P., Elias Júnior, J. and Nogueira-Barbosa, M. H. (2010): Severe paraquat poisoning: clinical and radiological findings in a survivor. J Bras Pneumol., 36(4): 513-516.

15. Novs, R. D., Gonçalves, R. V., Cupertino, M. C., Marques, D. C., Rosa, D. D., Peluzio, M. D. C. G., Neves, C.A. and Leite, J. P. V. (2012): Bark extract of Bathysa cuspidata attenuates extra- pulmonary acute lung injury induced by paraquat and reduces mortality in rats. Int J Exp Pathol., 93(3): 225-233.

16. Okolonkwo, B. N. and Nwachuku, E. O. (2013): The antioxidant effects of vitamin C on liver enzymes: aspartate aminotransferase, alanine aminotranferease, alkaline phosphatase and gamma-glutamyltransferase activities in rats under Paraquat insult. Journal of Xenobiotics.,3(1): 24-28.

17. Okolonkwo, B. N., Nwachuku, E. O., Ene, P. C. and Okeke, C. U. (2014): The preventive effect of vitamin C on the cellular and functional integrity of kidney cells in rats following repeated exposure to paraquat. Journal of Xenobiotics., 4(1): 29-39.

18. Papiris, S. A., Maniati, M. A., Kyriakidis, V. and Constantopoulos, S. H. (1995): Pulmonary damage due to paraquat poisoning through skin absorption. Respiration., 62(2): 101-103. 
19. Parvez, S. and Raisuddin, S. (2006): Effects of paraquat on the freshwater fish Channa punctata (Bloch): nonenzymatic antioxidants as biomarkers of exposure. Arch. Environ. Contam. Toxicol., 50(3): 392-397.

20. Pourahmad, M., Jahromi, H. K., Jahromi, Z. K., Sameni, M. H., Abedi, H., Kherameh, Z. K., Mohammadi, S. and Hosseini, M. A. (2016): The protective effect of Aloe vera on paraquat hepatotoxicity. International Journal of Medical Research and Health Sciences., 5(S): 253-258.

21. Sastry, K. V., Diqui, A. A. and Singh, S. K. (1982): Alterations in some biochemical parameters in the Dnake head fish Channa punctatus exposed clinically to quinalphose. Chemosphere., 2: 1211.

22. Shi, X., Zhang, Y. and Wang, Y. (2015): Impact of Xuebijing and ulinastatin as assistance for hemoperfusion in treating acute paraquat poisoning. Int J Clin Exp Med.,8(8): 14018-14023.

23. Snedecor, G. W. and Cochran, W. G. (1994): Statistical Methods. 8th Edn., Ames: Iowa State Univ. Press Iowa.

24. Suntres, Z. E. (2002): Role of antioxidants in paraquat toxicity. Toxicology., 180(1): 65-77.

25. Tavakol, H. S., Farzad, K., Fariba, M., Abdolkarim, C., Hassan, G., Seyed-Mostafa, H. Z. and Akram, R. (2015): Hepatoprotective effect of Matricaria chamomilla. L in paraquat induced rat liver injury. Drug Res.,65(02): 61-64.

26. Vale, J. A., Meredith, T. J. and Buckley, B. M. (1987): Paraquat poisoning: clinical features and immediate general management. Human Toxicology.,6(1): 41-47.

27. Vandenberghe, J. (1995): Hepatotoxicology: mechanisms of liver toxicity and methodological aspects. Toxicology: Principle and Applications., 718. 